\title{
THE DISCERNMENT OF SUBALTERNITY IN MAPS FOR LOST LOVERS BY NADEEM ASLAM
}

\author{
Murad Ahsan \\ Department of English \& Literary Studies \\ University of Management \& Technology \\ saimahsan677@gmail.com \\ Maryam Raza \\ Lecturer, Institute of English Studies \\ University of the Punjab \\ maryam.english@pu.edu.pk
}

\begin{abstract}
The research paper aims to explore the theory of Subalternism by Gayatri Spivak in Maps for Lost Lovers by Nadeem Aslam. The objective of the research is to unravel the streaks of hybridity and alienation in second generations residing in the diaspora. The study is undertaken with the lens of subalternity to delineate identity exploration, cultural hybridity, and insights of immigrants who struggle within their fluidity of identity. The study fills the gap in research by unmasking cultural subalternity in Aslam's novel which has not been critically studied in such a manner hitherto. It targets the multicultural society where immigrants face racial, stereotypical notions and internalize their individuality. Subalternity and Cultural Hybridity, with a specific focus on conservative fundamentals of naturalized hypocritical culture, is the tool for the research paper. The study highlights the significance of Post-Colonial literature, which manifests the dichotomy of a lack of identity for immigrants residing abroad as a minority \& a simultaneous prevalence of roots. It is qualitative research with a specific focus on the grounded theory pattern. It is a non-inter disciplinary research.
\end{abstract}

Keywords: Diaspora, Cultural Identity, Subalternity, Alienation, South Asian Literature, Post-Colonial Literature.

\section{INTRODUCTION}

The study focuses on subalternity and cultural hybridity in the novel Maps for Lost Lovers by BritishPakistani novelist, Nadeem Aslam. The paper aims to conceptualize the insight of immigrants, from the notion of a subaltern and social hierarchy, which questions their hybridity and rootlessness. The purpose of the study is to contextualize the story through different characters of the novel in a global scenario, which targets different minorities of Muslims, Hindus and Sikh families living abroad in the form of subalterns. It targets the representation of history in a new manner where the subaltern speaks on their own for their individuality and oneness. Thereby, answering Spivak in the affirmative that yes, a subaltern can finally speak in Nadeem Aslam's literary space. The research highlights the domain of patriarchal power, which perceives a woman as a form of a commodity by using religion and culture. The study also analyzes the generation gap within immigrants' families, where older generations take their cultural norms and values as a form of haven in a new land. However, the younger generations start to adopt their host's culture as a form of modernity. The study focuses on the social hierarchy, where the Western Self's culture dominates over the hostile, or rather inward shrinking psychology of the displaced Other, in terms of their linguistical and cultural lifestyle. Furthermore, the atrocities of a misogynist culture deprive the female characters of their representation and basics rights. However, the researcher undertakes a painstaking analysis to categorize the variety of submissive and deviant females prevalent in the text. The theory of subaltern also explores the penetration of third world feminism fitting into a multicultural society in an alienated land.

Nadeem Aslam is a British-Pakistani diasporic writer, who was born in 1966 in the district of Gujranwala of Punjab. At the age of fourteen, his family moved to West Yorkshire of London where he started to settle in a new multi-cultural society. He is a diasporic, British Pakistani writer, who now lives in the lakeside setting of the countryside. His parental background was typically conservative His first novel, 'Season of the Rain birds' written in 1993, acquired him global acclaim as a new contemporary British-Pakistani diasporic writer. His work mostly centers around immigrants, who get to adopt a new 
culture in a cosmopolitan society. He is known for exhibiting enriched characters and plots that intensify the setting of the native side of Pakistan. He contextualizes the internal issues of Pakistan, in the context of the Post-Colonial Era. His writing style focuses on the localized population but also discusses the global scenario of how living abroad can influence minorities.

In the novel Maps for Lost Lovers, the setting is an unknown town, Dasht-e-Tanhai, which means the Desert of Loneliness. The story centers around multifarious marginal communities, namely Hindus, Muslims and Sikhs, who are surrounded by white people. The story starts with the disappearance of Chanda and Jugnu, who were lovers and lived together without the bondage of marriage. Jugnu is a young lover of Chanda, whereas Chanda is a thrice-divorced middle-aged woman who falls in love with Jugnu. After their disappearance, Chanda's brother is accused of murdering both lovers in the name of honour. The story starts with the third narrators, Shamas and Kaukab. Shamas is Jugnu's older brother. Shamas is a sixty years old man who is very fluent in English and not as conservative as the other characters who lived in Dasht-e-Tanhai. The protagonist, Shams is a character who is more adroit in his speech and the cognitive sphere. Whereas, his wife Kaukab is depicted as a typical woman who completely denies the new modern values of the western world.

The subaltern studies rose to prominence in the 20th century after the colonization of the third world. The term Subaltern was used for the very first time by philosopher Antonio Gramsci, who referred to the working-class of the Soviet Union. The Subaltern was particularly used by him for the peasants and working-group. Gramsci was very much interested in the historiography of the working-class. He inculcated the ideology that the ruling class considers the working class as their subordinate. The former builds their hegemonic power and become the elite class. Thus, Subaltern means to belong to an InferiorRank. It is a term to confine one in the realm of the marginal or a minority; hence the deprived class. Later on, different scholars of the post-colonial era started to debate over the term. Subalternity in the post-colonial era tends to highlight the systemic discussion, which covers the subordination of South Asia irrespective of gender, class, race or creed. As time ensued, a group of five scholars: Ranajit Guha, Shahid Amin, David Arnold, Partha Chatterjee and Dipesh Chakarbatery produced the subaltern studies based on five different volumes that covered history, economy, politics, identity and sociology. The study of five volumes allowed these five scholars to speak for the people who had no voice at all.

Soon critics such as Gayatri Spivak, Ranjit Guha, and Edward Said internalized the idea of subaltern and orientalism in their work. Spivak's essay 'Can the Subaltern Speak?' was published in 1985, which substantiates the idea of how a subaltern is made voiceless. Whereas, Edward Said displayed his work on Orientalism that presumes the post-colonial era in monolithic expression. However, Spivak adapted the Derridean deconstructive technique in terms of using subject formation and the concept of othering. She presents the ideology that it is impossible to raise the voice of a subaltern by having an intersected patriarchal society. She highlights that the subaltern needs to speak on their own but patriarchy demands them to speak according to the phallocentric narrative or become silent. The elite class, being the male gender, normalizes the hypocritical society where a subaltern finds his silence much comforting and easier than to raise the voice and speak. Lata Maani is a critic who worked on subaltern studies and she commented that native men have found a way to speak, but women have struggled through it. "Hierarchy, self-representation is almost impossible" (Mambrol, 2016). Consequently, Lata Mani challenged in her work and asserted that a subaltern should get their voice back; recover and regain their identity, re-presentation, and attain their voice back. (Mamboral, 2016).

Put simply, the subaltern studies are a combination of Marxism, Post-structuralism, Gramsci, Foucault, and the incessant tussle between the West and South Asia (specifically India). True to form, Spivak reckons that the colonial masters fled the subcontinent but their language and influence still reeks in the minds of the slaves residing in India and Pakistan. The voice of the latter is silenced even in the physical absence of the colonial master (Mambrol, 2016).

The research work illustrates the following questions:

1. What does the title of the novel signify?

2. How does living in a multi-cultural society influence an immigrant's life? Do they create their new space or do they stick to their roots?

3. Does Kaukab exemplify the portrayal of a true subaltern or does she evoke self-imposed isolation?

4. Does religion lead immigrants to fundamentalism and evoke extremity within them? 
5. Has Nadeem Aslam broken the shackles of western scholarly discourse about the Muslim culture or does he propagate it for a western audience?

\section{REVIEW OF LITERATURE}

Maps for Lost Lovers has attained worldwide acclaim for its diction and characterization. True to form, it has been deemed to be "impressive (and) ... stylistically dazzling ... His characters' inner lives are explored in-depth" (Amazon, n.d.). He provokes his readers by depicting such characters that connect with readers at a very deep level and exhibit realistic imagery of our lives. Most of his work depicts the clash between modernization and tradition. He also targets the generational gap between two generations that live as immigrants. Whereby, the old generation provokes the values of their heritage, by the new generation has a proclivity for modernity. "Aslam overstates and sentimentalizes selfless saintly decency, and drowns the story in a gratuitously exotic and sensuous hothouse atmosphere evoked by ludicrously strained imagery.... Often exquisite; too often, too much of a good thing" (Kirkus, n.d.). His work serves as a vehicle that enables other to understand the struggle of people that belong to a third space and find a resilient force from a multi-cultural society that ends up depriving them of their fluidity of identity.

Akash Kapoor comments that "Aslam reveals-artfully and heartbreakingly-a psychology at war with itself . . His prose is richly atmospheric, his tone engagingly introspective" (New York Times Book Review 2004). Aslam maintains the margin of classes based on their linguistic and cultural distinction. Furthermore, "Aslam personifies the conflicts of acculturation, crafting a truthful story that resists easy conclusions" (Publishers Weekly, n.d.).

Maps for Lost Lovers has gained popularity in the global market as the characters are more complex in terms of their individual choices. However, Aslam has rationalized them enough to appeal to the readership around the globe. The novel is considered a success as it is "Extraordinary (and) it deepens our knowledge of life" (The New York Review of Books, 2004). Jonna Antoniak comments that "Maps for Lost Lovers is the celebration of customs and tradition brought to England from Pakistan." (Antoniak 2018). This means the subjectivity of the novel focuses on blending one culture into the host's culture. A migrant reveals his dilemma when he cannot or does not present his fluidity of identity verbally, thus becoming a subaltern. "This is that rare sort of book that gives a voice to those whose voices are seldom heard" (The Observer 2004).

Jonna Antoniak comments about Aslam's characterization as "Primitive in their willingness to subject themselves to the tradition of their lost homeland" which again embarks on the idea that a subaltern does not find enough room neither for him nor his beliefs" (Antoniak, 2018). Antoniak expands the idea that a subaltern gets no help at all socially nor individually; eventually, he goes back to reclaim his identity back on his own. However, when he does it, he dislocates his existence from the outer world and ends up being an alien and subaltern. A critic, Butt, shows the side of "foreign alien culture" where the old generation lives in a diasporic society by restricting themselves within the shells of their own culture and impose self-exile both internally and externally. The study also explores (Shaheen and Qamar, 2019). Kanwal trauma in characters at the behest of migration, loneliness, and displacement as they feel detached from their homes and settle themselves in an alien land. (Shaheen and Qamar, 2019). McCulloch (2012) points out in the novel the "danger of in-betweenness, and rootlessness and the unwillingness to accept the fluidity of identity in the global world" (Shaheen and Qamar, 2019). He points out the issues of intersectionality of genders and race in a multi-cultural society, which eradicates their beliefs and cultural values in a plural society. Sarfraz throws light upon the "representation of image in a postcolonial text by using the perspective of Foucault and E. Said, (to) illuminate the function and power of presentations in creating image in the mind of readers" (Shaheen and Qamar, 2019). Spivak, reckons that "a transaction between the speaker and listener" does not only center around the utterance of words, but also considers the dynamics of society as a metaphor. The subaltern is either made silent or misunderstood. Spivak also introduces the concept that "We are never looking at pure subaltern, there is, then, something of a nonspeakingness in the very notion of subalternity" (De, Gosh \& Jana, 2012).

On the contrary, Robert J.C opines that women seem to have their sustained image within a patriarchal society. Rather a woman is presented as an object that satisfies and exaggerates the power of male dominance on the level of social status and domestic subordination.

Homi K Bhabha explains that "The Other loses its power to signify, to negate, to initiate its historic desire, to establish its own institutional and oppositional discourse" (De, et.al, 2012). Thus, 
Spivak's subaltern is Bhabha's Other entity. He asserts that the Other conceals itself within the boundary of the subaltern.

Nevertheless, Parry suggests "absolute power to the hegemonic discourse" of patriarchy in which he targets Spivak's narrative as weak and fragile to stand on its own (Mambrol, 2016). He says that the subaltern was never silent or marginalized; instead, they were spoken by Homi k. Bhabha's theory of hybridity which represented their narratives and interpretations. He further asserts the idea that colonists had accentuated the voices of native people. (Mambrol, 2016).

Unlike Miquel Pomar- Amer's analysis in "Kaukab in Maps for Lost Lovers, by Nadeem Aslam: Representing and Subverting the Unspeakability of the Subaltern", the researcher focuses on not only exploring different individuals of minor communities as subaltern who force their own liminal spaces on themselves. Rather the study strongly unleashes the philosophical extraction of their individual choices through which language and which words they prefer to speak. It is felt and construed in the research paper that a subaltern even speaks through his silence. The silence itself forces an idea of being unfamiliar in the host culture. Thus, the immigrant manifests discomfort toward through the power of silemce for he chooses to stay quiet of his own accord. A subaltern no longer needs to learn the host language and transmit the idea that he is no longer interested in his intrinsic values and language. Since language is preferred as a matter of linguistic imperialism, the character of Kaukab herself shows her unease through her silence. On the contrary, Shamas finds and creates his new identity.

Consequently, the paper varies and open ups more aspects of multi-diversity and complexity of a subaltern that he may enforce silence upon himself or may speak, as per his will and as a symbolic assertion same time that Subaltern do speak; either linguistically or symbolically.

\section{RESEARCH METHODOLOGY}

The research entails a content-based, textual analysis of Nadeem Aslam's novel Maps for Lost Lovers as the primary text. The applied theoretical framework is Gayatri Spivak's "Can the Subaltern Speak?" Reviews pertaining to the aforementioned author, novel and theory also form the secondary sources for the thesis. Both, print and electronic media, have been utilized as a secondary source. It is a qualitative research with a specific focus on grounded-theory style. It is an inductive study and not interdisciplinary. The thesis will open new avenues for the novel as a critical study based on existentialism. The significance of this research lies in the use of subaltern theory and imperialist patriarchy to evade psychological trauma lurking in the minds of immigrants residing in the West.

\section{DISCUSSION AND ANALYSIS}

The thesis highlights the different issues of immigrants who live abroad by depicting their cultural and identical hybridity. Thus, Maps for Lost lovers examines socio-political issues in a multi-cultural society. Aslam's novel signifies the importance of the roots and connection with one's own home. The word Maps in the title refers to a roadmap that has its roots and a sequence. Maps serve those who either do not know their roots at all or have not been there for ages. Maps are a vehicle in a storyline for characters to trace their roots back by following the roadmap. The word also holds the power of authority for guiding the lost lovers. However, Maps have not been granted for everyone by the writer. It has been restricted to only those who are either Lost or Lovers. The map is only designed to guide those who are either lost and long of going back to their roots or those who believe in love and long for it. The word Lost accentuates the notion of Nothingness and liminality. Thus, characters figure out their belonging and roots or one could be lost in a domain of two cultures, identities or existence which lead them into nothingness eventually. The word Lovers defines those who are lovers, as a representation of their identity. They are those who are in love with the inception of a self-created identity or one hurled onto them.

Fromm presents his theory in his well-known published book "Art of Loving" which resolves the idea that love only seems to be a solution for all problems of mankind. He instils the idea that the complexity of human should be rectified by loving others and spreading the love for others. (Shaheen and Qamar, 2019). He resists the idea that humans are too rationalized by figuring out the solutions. They should simplify the complexity of their problems by loving others and forgiving them. Aslam has also referred to the same Maps that is for the Lost Lovers, who want to go back to their homes. According to Fromm theory, Aslam believes love to be an eternal power that can heal and save humanity. He extends Fromm's ideology further that love is the only solution for humanity and those who seek love are not Lost 
anymore. Consequently, Aslam solves the mystery by his very own title: Maps for those who are Lost Lovers.

Aslam has subjected both Maps and Lovers in plural form, which means he does not specify Maps just for Chanda and Jugnu. It is even for those who exist in any corner of the world and can have the same maps because their subjectivity relates to Love and affection. Furthermore, Maps have not been only constrained and restricted for one specific gender. The words Lost Lovers in the title do not confine or restrict any gender specifically. This strengthens Fromm's idea of the Union of both genders at the same time. He constructs the argument that the separation of both genders should base on their distinguished roles in a society, rather than building the dichotomy of strong and weak. Therefore, he sees love as a vehicle to simplify all issues of humankind.

In the novel, a couple, Shamas and Kaukab, take refuge from Pakistan in England for political and financial stability. Both of them incisively saw the foreign country as a chance to bring their life toward prosperity and safety. For Shamas, England gave him hope of a better life. He sets his residence in a small town of England, called, Dasht-e-Tanhai. It is an Urdu word, meaning dwelling of sorrow. Thus, it is evident that it is a fictional place in England. Kaukab seemingly accepts her husband's decision and adjusts to fit into the town, known for its isolation and suffocation. In a multi-cultural society, Kaukab appears as a woman, who looks after her home and takes care of her family. She does not learn English at all in Dast-e-Tanhai for two reasons. Firstly, she occupies herself within her home for the sake of her comfort. Secondly, she finds white people as "dangerous" and "shameless" and "idiotic." (302). After coming to Dasht e Tanhai, she had two options viz, either to engage herself in a new cultural setting or to stick to her old traditions. The dichotomy of modernity and tradition has been depicted in Kaukab's character. "Even the things spoke a different language than the one they did in Pakistan." (35).

She uses language, culture and religion as a barrier to separate herself from the rest of the white country. She perceives the English language as alien and difficult for expressing her point of view and feelings. Although Kaukab knew that her family took refuge in a western country for the betterment of their personal and social life; she still resents that the western country is a "Nest of delivery where god has been exiled." (30). Rather than using the opportunity to explore herself in a new place, she restricts herself in her home using some excuse or another to not speak English. She carries her dilemma along with her in a new country and self-isolates by saying that white people are "diseased, vice-ridden and lecherous race" (44). She longs to go back to her homeland, which means that she refuses to accept the new culture.

Dasht e Tanhai is perceived geographically and metaphorically to uncover the understanding that immigrants are marginalized and decapitated from the city. In Britain a woman can possess the same rights and control as a man can have, but the female character in Aslam' novel somehow projects the extreme version of herself who believes that Islam does not allow her to go out alone, and prohibits any contact with a Na-Mehraam (man other than father/brother/husband). Whereas, neither the society nor her religion imposes this restriction upon Kaukab. Kaukab claims that "I won't move to Pakistan. What would my life be then?" This also depicts motherly instincts that she does not want to go back to Pakistan because her children live in England. (146-147). On the other hand, "My heart is in Arabia" means that her spiritual connection with Islam is firmer and she uses her religious belief which resonates with her discomfort from a Christian country. She willingly marginalizes herself from their law and society altogether. She makes her religion and tradition a barrier for her that gives her comfort and security. Consequently, the host culture was not responsible for misinterpreting her. It was her own will that made her alien to them. She refused to wear western clothes and learn their language. She created her own limited space; which eventually cornered her from the rest of the world. Thus, she became a subaltern by her own will. She resorts to self-imposed loneliness and isolation in her small community for the sake of her psychological comfort.

Aslam has also explained what it is to be in the third space in his novel. It is felt that the daughter of Shamas and Kaukab, Mah Jabin, is a female character that internalizes the concept of living in the third space. She was born in England and perceived as a girl, who understands and speaks English fluently and cherishes her life as a mimic, as per ideology. She wears western clothes and sees the world with a modern view. Unlike her mother, Mah Jabin believes in modernity and assertiveness, enjoys an exciting and colourful life. Whereas, Kaukab exhibits the life of exile, even in a free country. Kaukab ends up silencing her voice in a foreign country and marginalizes herself from it. Whereas, Mah Jabin becomes one of the girls who live among white people and internalizes their culture and identity. At last, her 
connection with her roots become so fragile that she forgets where she belongs from. Both women lie in the extremity of their behavior and create a very strong dichotomy of passiveness and activity. Mah Jabin explores herself creating an active voice, unlike her mother who chooses to remain passive. However, it the act of choosing to remain passive which also confers Kaukab a warped sense of active display of identity.

Furthermore, when Kaukab forced her daughter to marry her cousin in Pakistan, it was a form to explore the gap between Mah Jabin and her roots. She went back after two years and divorced her husband according to the British law. Kaukab on the other hand, wanted her to end the marriage according to Islam: "In the eyes of Allah, you are still married to him. You may have divorced him under British law, but haven't done so in Muslim court." (164).

Mah Jabin's discomfort in fulfilling Islamic Shariah shows her unfamiliarity with Pakistani laws. She was raised in the West and then she created her own liminal space where she forgot her roots. She expresses radical behavior that contradicts her fragility in her belief in Islamic doctrines. She sees her mother as a religious fundamental while her mother sees Mah Jabin as a hopeless liberal. Both female characters devalue one another's views. Mah Jabin is classified as subaltern for her mother while she earns the same label for the former.

True to form, according to Spivak; "We are never looking at the pure subaltern. There is then, something of a non-speakingness in the very notion of subalternity." (De, 2012). Kaukab keeps herself away from the white world and restricts herself within her own home. She gains comfort by embracing her first language and culture within her home, which strengthens the understanding that she creates her space of dominance, where she speaks and lives according to her comfort and proclivity. "I don't go there often- white people's houses start soon after that street, and even the Pakistanis there are not from our part of Pakistan." (66).

Kaukab is unable to speak in public due to her poor English. This is a form of silencing her but it is noteworthy that this failure is self-imposed. It is felt that Kaukab was unable to speak by dint of her own choice and will. On the contrary, her daughter goes out and accepts the host culture. "She would have been exactly like this if she weren't here in England. What were her achievements back in Pakistan?" (323). In England, Kaukab was rejected based on her linguistic and cultural difference, but even in Pakistan, she was a subaltern from having resided in the West. It is felt, that the space of a subaltern is not a matter of objectivity at all. Rather, it is a matter of an individual's willingness to either submit or to speak for themselves.

Shamas, who is the husband of Kaukab and father of Mah Jabin, also creates a liminal space that shows a tendency towards modernity and accepts the new culture as an opportunity for making his family life better. Shamas indulges in a new culture; speaks English fluently, drinks wine and has affairs with white girls. He even becomes an atheist after going to a non-Muslim country. Shamas aligns himself on the side of secularism and socialism. He helps other communities, including Sikhs (Kiran and Family), Hindus (Poorab Jee) and the Christian community. Unlike Kaukab, he does not differentiate among others based on their religion, culture or creed. He nourishes his personality and becomes more socially active by helping others for the sake of being a good citizen. Aslam has not portrayed him as a bearded religious extremist rather as a man who lives among white people and project a perfect embodiment of a subaltern. He maintains the value of his own culture in his private domain. Yet in his public space, he speaks English and accepts western ideologies. As a result, he creates his liminal space, where he is neither of them. Shamas explicates the idea that cultural multiplicity can be positive in terms of becoming a man who maintains a balance between the new and old tradition.

The character of Shamas maintains both ends of his belonging and finds a place in his inbetweenness. He celebrates his hybrid identity and affirms that neither history nor identity can restrict in one space. Rather it makes one flexible to accommodate new changes in society. "For me the importance of hybridity is not to be able to trace two original moments from which the third emerges, rather hybridity to me is the third space which enable other position to emerge" (Bhabha's Hybridity and, n.d.).

Nadeem Aslam has tackled the idea of Bhabha's cultural hybridity as a hybrid that exists somewhere in-between. Shamas and Mah Jabin exist within their in-betweenness. They neither completely live in their past roots, nor their future. They create their meaningful purpose out of their meaningless life. Bhabha states that "find (your) agency in a form of the future where the past is not ordinary, where the present us not simply transitory." (Bhabha's Hybridity, n.d.). 
True to form, Shamas and Mah Jabin neither depen on their past nor dwell in their future. They constantly shift their identities between newness and become a part of a multi-cultural society. Where they prefer being socially active and live life on their own. Shamas and Mah Jabin both amplify the meaning of their own and project a positive side. On the other hand, Kaukab seems to inflict upon herself a trauma in a new country, where she does not indulge herself to be part of it and she becomes a subaltern by her own choice.

Put simply, the study infers that Nadeem Aslam lays the burden of subalternity upon Islam. He projects a vile and idiotic re-presentation of the religion which endures suffocation and isolation, rendering to the formation of a subaltern. On the contrary, Aslam donates bliss to lie in the liminal zone. Thus, the study proves that Nadeem Aslam equates adherence with subalternity and Tanhai as seen in the case of Kaukab. Whereas, joy and comfort prevail for mimics such as MahJabin and Shamas.

\section{CONCLUSION}

In Maps for Lost Lovers, living abroad gives a chance to immigrants to construct their own identities. Residing in a multi-cultural society allows each individual to create their own private space where they create their new identity. The character of Kaukab puts on a garb of Subaltern willingly and shuns all the western marks based on her fundamental perception of Islam. Hence, she does not learn English at all to depict her dedication to her ancestral roots of Islam. She inculcates the notion of conservative fundamentalism by imposing self-isolation in Dast e Tanhai. England itself does not deprive or drain her identity. It was her own self which put barriers between herself and the society. Consequently, she becomes a subaltern. On the other hand, the character of Mah Jabin, was raised in England by Kaukab, yet refuses to accept any trauma from her mother. She lives among the white people, dresses like them and adapts their lifestyle. Consequently, she fails to maintain a healthy balance between her roots and the host culture. Eventually, she becomes one of the recovering patriarchal victims and despises the patriarchal culture altogether. Moreover, she forms her own identity in the third space of liminality.

Lastly, Shamas becomes an atheist and cosmopolitan. He speaks English fluently and lives among white people. He morphs his identity completely: from a Muslim to an atheist. He creates his own space where he interacts with families of other religions and prioritizes humanity over religion.

Put simply, Shamas and Mah Jabin shift their identity and lose their connection from their roots and religion. Whereas, Kaukab becomes a religious fundamentalist and falls into the category of extremity. Mah Jabin and Shamas show discomfort towards religion. They become liberals and socialists. It is felt that all three characters portray a warped form of religious fanatism and religious fundamentalism where either religion is accepted blindly or ignored completely.

It is also noteworthy that Nadeem Aslam has constructed a reductive image of Islam. He does not employ any effort at all in breaking the shackles of the negative portrayal of Islam that has been manifest by western scholars for centuries. He does not differentiate Islam from fundamentalism. In lieu of that, he delineates religion and fundamentalism to be in the same category. He inculcates the idea that Muslims can only exist on extremes of radicalism or sheer liberalism. There is no middle ground for a Muslim to exist. Moreover, he implants the ideology that Islam stops its followers from socializing, gives a lower status to woman, encourages barbarism in the name of honor killing and ironically believes in superstition. All these claims are false but the writer never refutes them to rectify the re-presentation of Islam in the Western world. It is almost as if he caters to a western audience at the cost of his own roots. Thus, Aslam endorses western discourse that subjugates the image of Islam as a hindrance to the successful and useful lives of subaltern immigrants.

\section{REFERENCES}

Antoniak, Joanna. (2018). A female perspective on exile in Nadeem Aslam's Maps for Lost Lovers. At a time of Crisis: English and American Studies in Spain, 176-181. https://cafedissensus.com/2018/05/04/a-female-perspective-on-exile-in-nadeem-aslams-maps-forlost-lovers-2004/.

Arif, Dr. Shahbaz and Nighat Parveen (2014). Cultural Hybridity in Nadeem Aslam's Maps for Lost Lovers. Research on Humanities and Social Sciences, 4(25): 57-65. https://www.iiste.org/Journals/index.php/RHSS/article/download/17554/17752\#: :text=Maps\%2 Ofor\%20Lost\%20Lovers\%20seems, these\%20two\%20prominent\%20literary\%20figures.

Aslam, N. (2004). Maps for Lost Lovers. Vintage Publishers. 
Everettsd Organization. (n.d.). Bhabha's Hybridity and the Third Space in Post Colonial Discourse. Retrieved from: https://www.everettsd.org/cms/lib07/WA01920133/Centricity/Domain/965/Meredith.pdf.

De, A, Ghosh A and Jana U. (Ed.). (2012). Subaltern Vision: A Study in Post colonial Indian English Text. Cambridge Scholars.

Kirkus. (n.d.). Maps for Lost Lovers. Retrieved from: https://www.kirkusreviews.com/bookreviews/nadeem-aslam/maps-for-lost-lovers/.

Mambrol, Nasrullah. (2016). Subaltern (Post colonialism), Literariness. https://literariness.org/2016/04/08/subaltern-postcolonialism/.

Pomar-Amer, Miquel. (2012). 'I Want You to Listen to Me'; Overcoming the Subaltern's Unspeakably in Nadeem Aslam's Maps for Lost Lovers. At a Time of Crisis: English and American Studies in Spain,

176-181. https://www.academia.edu/3394332/_I_want_you_to_listen_to_me_Overcoming_the_Subaltern_ s_Unspeakability_in_Nadeem_Aslam_s_Maps_for_Lost_Lovers.

Publishers Weekly. (n.d.). Maps for Lost Lovers. Retrieved from: https://www.publishersweekly.com/978-1-4000-4242-5.

Sarfraz, Sijal. (2013). Representation of Islam: A Postcolonial Reading of Nadeem Aslam's Maps for Lost Lovers. Academic Research International, 4(3): 502-512. http://www.savap.org.pk/journals/ARInt./Vol.4(3)/2013(4.3-51).pdf.

Shaheen, Aamer, Sadia Wamar and Nazia Kirn. (2019). Love as a Force for Women's Liberation and Identity in Nadeem Aslam's Maps for Lost Lovers. The Journal of Humanities and Social Sciences, 27(1). http://journals.uop.edu.pk/issue detail.php?issue id=161\&journal id=12. 